\title{
Erratum to: Massive panniculectomy and hernioplasty as a salvage procedure
}

\author{
R. Matasa - C. Zirak - P. Mendes da Costa - A. De Mey · W. Boeckx
}

Published online: 29 October 2013

(C) Springer-Verlag Wien 2013

Erratum to: Eur Surg (2013) 45:230-234. DOI 10.1007/ s10353-013-0194-z

In the published original article, the family name of the third author is not given correct. The correct name is:

P. Mendes da Costa (not P.M. da Costa).

The online version of the original article can be found under doi: http://dx.doi.org/10.1007/s10353-013-0194-z

R. Matasa $(\square) \cdot$ C. Zirak · A. De Mey $\cdot$ W. Boeckx

Department of Plastic Surgery, Brugmann Universitary Hospital,

4 Place van Gehuchten, 1020 Brussels, Belgium

e-mail: roxanamatasa@yahoo.com

P. Mendes da Costa

Department of Digestive, Thoracic and Laparoscopic Surgery,

Brugmann Universitary Hospital, Brussels, Belgium 